\title{
Dispersal of Spores of Fusarium culmorum in Aquatic Systems
}

\author{
M. L. Smither-Kopperl, R. Charudattan, and R. D. Berger
}

Department of Plant Pathology, University of Florida, Gainesville 32611.

Accepted for publication 6 February 1998.

\begin{abstract}
Smither-Kopperl, M. L., Charudattan, R., and Berger, R. D. 1998. Dispersal of spores of Fusarium culmorum in aquatic systems. Phytopathology 88:382-388.

The dispersal of spores of Fusarium culmorum, a biological control agent for the aquatic weed Hydrilla verticillata, was investigated in aquatic systems. Macroconidia and chlamydospores that were applied to the surface of the liquid settled rapidly in deionized water, tap water, 5\% Hoagland's solution, natural spring water, or river water held in glass

rate of $>9 \mathrm{~m} \mathrm{~h}^{-1}\left(15 \mathrm{~cm} \mathrm{~min}^{-1}\right)$, approximately 100 times faster than the rate of settlement. The spores attained an even lateral distribution in a still, closed system. Spores dispersed rapidly in moving water and were transported with the water current. Spores were determined to carry positive electrostatic charges as they migrated towards the negative pole during electrophoresis. The physical components of dispersal of $F$. culmorum spores were defined in a still aquatic system to consist of rapid lateral dispersal and sinking due to gravity. In moving water, the dynamics of water movement was superimposed over the other two factors.
\end{abstract} containers. The rate of fall, as measured for $50 \%$ of the spores, was determined to be $9 \mathrm{~cm} \mathrm{~h}^{-1}$. Rapid lateral dispersal of spores from a point source occurred in still water. This initial spore movement occurred at a
Additional keywords: spore dispersal, submerged aquatic plant.
The exotic, invasive, aquatic weed Hydrilla verticillata (L.f.) Royle (hydrilla) is a significant threat to freshwater resources in the United States. The weed poses serious environmental and economic problems in waterways, lakes, and rivers in Florida and the southeastern United States, and biological control offers the best hope for a long-term solution (2). Accordingly, a search was made for a pathogen capable of killing or weakening hydrilla and reducing its aggressiveness. A fungus, Fusarium culmorum (W.G. Smith) Sacc., was isolated from tissues of diseased Stratiotes aloides L. plants found in the Netherlands (5). This plant is a member of the hydrilla family (Hydrocharitaceae), and not surprisingly, the isolate of F. culmorum was found to be lethal to hydrilla in laboratory tests $(4,5)$. Based on host range studies, this isolate is not considered a threat to terrestrial plants, and, therefore, it should be safe for use as a biological control agent (3). The potential of $F$. culmorum as a biocontrol agent was obvious from small-scale laboratory tests, but larger-scale tests of this fungus on hydrilla were disappointing. The reasons for this were unclear because of a lack of knowledge of spore dispersal, infection, and disease development in the hydrilla- $F$. culmorum aquatic pathosystem.

Spores of fungi native to aquatic and marine habitats generally have branched conidia or appendages on their ascospores $(10,11)$. The diverse group of fungi known as the aquatic hyphomycetes includes members of the divisions Ascomycota and Basidiomycota, and these fungi play a major ecological role as decomposers of leaf litter in aquatic ecosystems. From studies of dispersal of this group, it is known that the appendages and the shape of spores reduced the rate of settling and increased the probability of spore attachment to a leaf surface in moving water (11).

The method of spore dispersal and encounter with the host is fundamental to understand the initiation of disease, and for many diseases of crop plants, the physical factors causing spore dispersal are well known. Wind has the potential to disseminate many

Corresponding author: M. L. Smither-Kopperl

E-mail address: MLSK@gnv.ifas.ufl.edu

Publication no. P-1998-0323-01R

(C) 1998 The American Phytopathological Society pathogens over long distances. The classic example is the annual movement of uredospores of wheat stem rust (Puccinia graminis f. sp. tritici) in North America (9). Potato late blight, caused by Phytophthora infestans, is dispersed by air movements within crops, but disseminated over long distances by infected vegetative material (6). Rain-splash is an efficient mechanism for localized dispersal of many pathogens within a crop, for example, Phytophthora cactorum on strawberry (8). Compared with our knowledge of crop diseases, the epidemiology of plant diseases in natural aquatic systems has not been studied, so we lack an understanding of the physical movement of spores of Fusarium spp. in water.

The aim of our research was to develop a model for disease development in the hydrilla-F. culmorum pathosystem that would facilitate development of an effective biocontrol strategy. The objective was to understand the movement of inoculum within the environment by determining the physical movement of macroconidia and chlamydospores of F. culmorum in still and moving waters, and so to predict the potential for contact between the spores and hydrilla. Portions of this work have previously been reported $(21,22)$.

\section{MATERIAL AND METHODS}

Production of macroconidia and chlamydospores. All experiments were conducted using the isolate of $F$. culmorum (621) isolated by R. Charudattan from $S$. aloides plants collected in the Netherlands and preserved by lyophilization (5). Macroconidia were obtained from cultures of $F$. culmorum grown on V8 juice agar (V8 juice, $200 \mathrm{ml} ; \mathrm{CaCO}_{3}, 3 \mathrm{~g}$; and agar, $15 \mathrm{~g}$ ). Cultures produced from hyphal tips were quite variable in appearance, including pigmentation and production of macroconidia. Hence, the following method was used to produce consistent cultures. Macroconidia were routinely removed from a 2-week-old culture using a dry, sterile, cotton applicator and streaked onto fresh plates. The plates were maintained at $25^{\circ} \mathrm{C}$ under fluorescent light with a 12-h day length for spore production. After 1 or 2 weeks, the plates were flooded with $5 \%$ Hoagland's solution plus $0.1 \% \mathrm{KHCO}_{3}$, with the $\mathrm{pH}$ of the solution adjusted to 7.5 (referred to herein as 5\% Hoagland's+). The culture surface was stroked gently with a sterile rubber spatula to dislodge the spores. The resulting suspension 
was filtered through four layers of cheesecloth. The concentration of macroconidia was determined using a hemacytometer and adjusted to either $10^{6}$ or $10^{7}$ macroconidia per ml. Macroconidia and chlamydospores were differentiated by microscopic observation. Chlamydospores formed inside macroconidia in cultures maintained on petri plates for 3 weeks. Macroconidia of any age, when stored in aqueous solutions, rapidly formed chlamydospores inside the macroconidial walls, so that $100 \%$ of the spores had formed chlamydospores within $24 \mathrm{~h}$. These spores remained viable within the intact macroconidial wall for more than 3 months, as evidenced by greater than $90 \%$ germination when the spores were transferred to solid media. Stock solutions of spores were maintained in 5\% Hoagland's + at $4{ }^{\circ} \mathrm{C}$ and used within 6 weeks. The term "spore" is used both for the endosporic chlamydospores from stock solutions and the freshly harvested macroconidia placed in aqueous solutions, since the behavior of both spore types was the same.

Aqueous solutions. Spring water was collected from the Manatee Springs, Florida, and river water was from the Suwannee River, Chiefland, FL. Analysis of these solutions in comparison with tap water and Hoagland's+ is shown in Table 1. The $\mathrm{pH}$ of spring water, river water, tap water, and 5\% Hoagland's+ was 8.1, 8.0, 8.6, and 7.5, respectively.

Spore quantification. Three methods were used to quantify spores. First, spores were counted with a hemacytometer for all initial estimates and also for high spore concentrations $\left(>10^{4}\right.$ spores per ml). Second, to count spore deposition per unit area, petri-plate bases $(60 \times 15 \mathrm{~mm})$ were used as traps. After settling in aqueous solutions, the spores adhered to the surface of the petri plates. This attachment was considered to be due to a hydrophobic-surface interaction between the spores and the petri plate $(16,17)$. The number of spores per three microscope fields of view was counted on the inside base of each petri plate. This method was also suitable to quantify spores per unit volume in the range of $10^{2}$ to $10^{4}$ spores per ml. A known volume of spore-containing suspension was added to each plate and left undisturbed for the spores to settle and adhere to the base of the plates. After $30 \mathrm{~min}$, three counts were made, as before, of the spores attached to the base, and these values were converted based on the known initial volume of the suspension to determine the number of spores per milliliter. Third, dilution plating was used to estimate low concentrations of spores $\left(<10^{3}\right.$ spores per $\left.\mathrm{ml}\right)$.

Spore settlement in still solutions. A $275-\mathrm{ml}$ volume of deionized (DI) water, tap water, 5\% Hoagland's+, spring water, or river water was placed in glass containers $(18.5 \mathrm{~cm}$ height $\times 4.3 \mathrm{~cm}$ inside diameter), and a suspension of $10^{6}$ macroconidia per $\mathrm{ml}$ was added evenly to the surface of the water as small drops. Samples of approximately $1 \mathrm{ml}$ were removed with a Pasteur pipette at depths of $1,4,7.5,11,14$, and $15 \mathrm{~cm}$ (the base of the container). To prevent disruption of spore settlement during sampling, the pipettes were slowly and carefully slid down the edge of the containers, and the sample was then taken from the center of the column. Sampling times were $0,0.5,1,1.5,2$, and $3 \mathrm{~h}$ after addition of the spores. Spore numbers were immediately quantified with a hemacytometer. Spore dispersal after $1 \mathrm{~h}$ was determined by sampling at depths of $1,4,7,10,13$, and $16 \mathrm{~cm}$ in DI water, tap water,
$5 \%$ Hoagland's+, spring water, and river water. The experiment was repeated to record the number of floating spores over 8 days. Containers were set up with tap water, 5\% Hoagland's+, spring water, and river water. Samples $(10 \mathrm{ml})$ were taken and quantified after $1 \mathrm{~h}$, and after 1, 2, 4, and 8 days.

Spore dispersal from a point source. The experiments were conducted outdoors in a metal tank with rounded ends $(290 \mathrm{~cm}$ long $\times 88 \mathrm{~cm}$ wide $\times 70 \mathrm{~cm}$ high) filled with tap water to depths of 10 and $50 \mathrm{~cm}$. A $15-\mathrm{cm}$ grid with external dimensions of $60 \times$ $150 \mathrm{~cm}$ was marked on the base of the container (Fig. 1A). Petriplate bases, as spore traps, were placed on each of the 55 grid intersections. Each plate was weighted at the center with a $4.7-\mathrm{g}$ metal weight. Spores of F. culmorum $\left(10 \mathrm{ml} \times 10^{7}\right.$ spores per $\left.\mathrm{ml}\right)$ were poured slowly onto the water surface in the center of the container. The tank was covered with a thick, clear, polypropylene sheet, above the water surface, to prevent wind-induced movement of the water. The tank was left undisturbed for the spores to settle. After $24 \mathrm{~h}$, the petri-plate bases were covered with petriplate tops, previously labeled with the grid coordinates, and removed from the tank. The spores per unit area were quantified as described above. The experiment was repeated twice at each water

\section{A Top view}

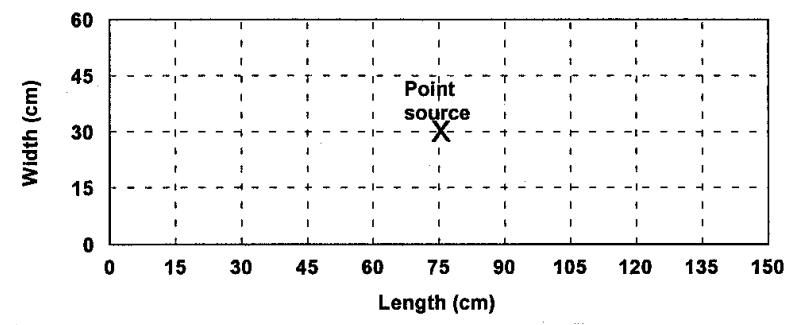

B Lateral view

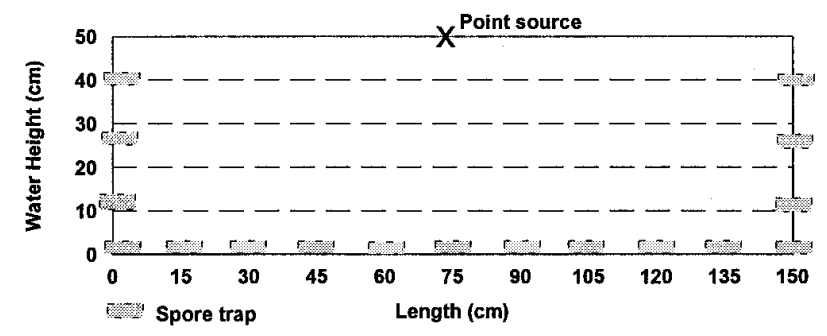

Fig. 1. Schematic diagram of sampling layout to investigate the lateral dispersal of spores of Fusarium culmorum in still water. Spores $\left(10 \mathrm{ml} \times 10^{7}\right.$ spores per $\mathrm{ml}$ ) were added at the point source. A, Viewed from top, petri-plate bases, as spore traps, were placed at 55 locations at the grid intersections and around the perimeter. After $24 \mathrm{~h}$, the petri-plate bases were covered with petri-plate tops, previously labeled with the grid coordinates, and removed from the tank. Spore counts per unit area were estimated from spore counts in three microscope fields of view. B, View from side at 50-cm water depth.

TABLE 1. Chemical analyses of aqueous solutions used for investigation of spore dispersal

\begin{tabular}{|c|c|c|c|c|c|c|c|c|c|c|c|c|}
\hline \multirow[b]{2}{*}{ Source $^{\mathrm{a}}$} & \multicolumn{12}{|c|}{ Concentration $(\mathrm{mg} / \text { liter })^{\mathrm{b}}$} \\
\hline & $\mathrm{pH}$ & $\mathrm{NH}_{4}$ & $\mathrm{NO}_{3}$ & $\mathrm{P}$ & $\mathrm{K}$ & $\mathrm{Ca}$ & $\mathrm{Mg}$ & $\mathrm{Fe}$ & $\mathrm{Na}$ & $\mathrm{Cl}$ & $\mathrm{Si}$ & $\mathrm{TOC}^{\mathrm{c}}$ \\
\hline Manatee Springs & 8.1 & 0.26 & 6.2 & 0.0 & 5.2 & 97.4 & 7.0 & 0.0 & 4.3 & 7.4 & 3.2 & 12 \\
\hline Suwannee River & 8.0 & 0.26 & 1.8 & 0.1 & 1.7 & 53.8 & 6.0 & 0.23 & 5.0 & 7.4 & 3.2 & 13.3 \\
\hline Tap water & 8.6 & 0.26 & 0.44 & 0.4 & 15.6 & 28.2 & 18.9 & 0.1 & 11.5 & 29.1 & 12.6 & $<2$ \\
\hline $5 \%$ Hoagland's+ & 7.5 & 0.52 & 36.2 & 14.9 & 506 & 1.8 & 0.7 & 0.1 & 7.3 & 0.7 & 8.7 & 34.1 \\
\hline
\end{tabular}

a Water was collected from the Manatee Springs, Florida, and the Suwannee River, Chiefland, FL.

b Samples were analyzed by the Analytical Research Laboratory, IFAS, University of Florida.

c Total organic carbon was analyzed by Advanced Technologies and Testing Laboratories, Inc., 13305 Rachael Blvd., Copeland Industrial Park, Alachua, FL 32615. 
depth. In addition, further samples were taken at 10,25 , and $40 \mathrm{~cm}$ from the water surface in the $50-\mathrm{cm}$ water depth. A retort stand with clamps was placed at each end of the sample grid and used to position petri-plate spore traps (Fig. 1B).

The experiment was repeated on a smaller scale in the laboratory in containers with the water temperature equilibrated at $21^{\circ} \mathrm{C}$. This excluded the possibility of convection currents dispersing the spores. The sampling method was chosen to determine the time for lateral dispersal of spores. Plastic containers $32 \mathrm{~cm}$ long $\times 42 \mathrm{~cm}$ wide $\times 12 \mathrm{~cm}$ high containing 16 liters of water to give a depth of $10 \mathrm{~cm}$ were left overnight for the temperatures to equilibrate. The eight spore traps consisted of 26- $\mathrm{mm}$ lengths of PVC pipe $(22 \mathrm{~mm}$ outside diameter and $15 \mathrm{~mm}$ inside diameter) with a $6-\mu \mathrm{m}$-mesh screen glued to one end, to trap spores of $F$. culmorum and allow movement of water (Fig. 2). These PVC-pipe spore traps were arranged vertically as an octagon at a distance of $15 \mathrm{~cm}$ from the center. The PVC-pipe spore traps were removed with forceps by lifting vertically up through the water column to trap the macroconidia. Weighted, petri-plate base spore traps were placed in the center and in the four corners of the plastic container at a distance of $30 \mathrm{~cm}$ from the center. Spores $\left(1 \mathrm{ml} \times 10^{7}\right.$ spores per $\left.\mathrm{ml}\right)$ were released on the water surface in the center of the tank. The PVC-pipe spore traps were removed at $0,1,2,3,4,5,10$, and 60 $\min$ or $0,5,10,15,20,30,45$, and $60 \mathrm{~min}$ after spore release. The number of spores was determined using the petri-plate method as previously described. Spores per unit area were estimated from the petri-plate spore traps placed inside the containers and removed after $24 \mathrm{~h}$. The experiment was conducted six times for each sampling period.

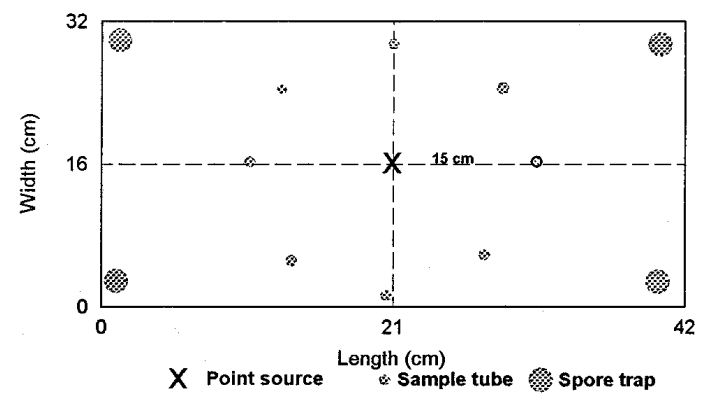

Fig. 2. Schematic diagram of sampling method to investigate the lateral dispersal of spores of Fusarium culmorum in still water over a limited time period. Spores $\left(1 \mathrm{ml} \times 10^{7}\right.$ spores per $\left.\mathrm{ml}\right)$ were added at the point source. The eight spore traps located $15 \mathrm{~cm}$ from the center were removed at timed intervals, and the spores were quantified using the petri-plate method as previously described. Spores per unit area were estimated from the petri plates placed inside the containers and removed after $24 \mathrm{~h}$.

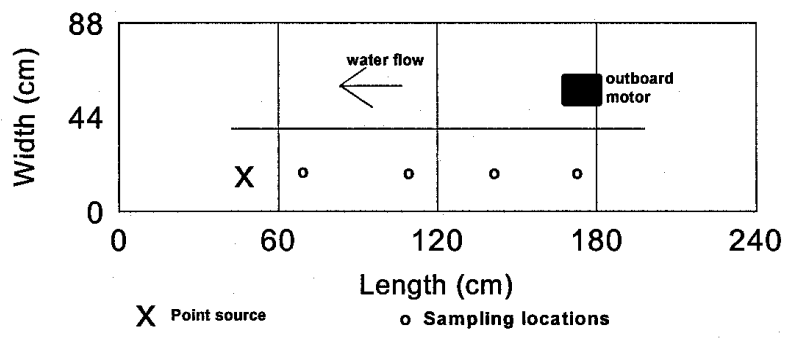

Fig. 3. Schematic diagram of sampling method to investigate dispersal of spores of Fusarium culmorum in moving water. Viewed from top. Spores $(10 \mathrm{ml} \times$ $10^{7}$ spores per ml) were added at the point source. Spore samples were taken at four locations from the point of dispersal $(10,50,90$, and $130 \mathrm{~cm})$, and at depths of $10,20,30$, and $40 \mathrm{~cm}$. Spore concentration was quantified per unit volume at flow rates of 1,5 , and $10 \mathrm{~cm} \mathrm{~s}^{-1}$.
Spore dispersal in moving water. Spore fall in moving water was investigated in the metal tank described above filled to a depth of $50 \mathrm{~cm}$. The container was partially divided longitudinally by a painted wooden partition held in place by three cross-beams (Fig. 3). A 30-cm space at each end of the container allowed circular water movement. A trolling motor (Transom Classic 35a; MinnKota, Mankato, MN) was suspended from one of the beams into the water. The speed of the trolling motor and, hence, the rate of flow was adjusted with a rheostat connected between the trolling motor and a $12-\mathrm{V}$ battery to give standard rates of flow of the water around the tank. Flow rates were determined using a flow meter (portable water current meter, model 201; Marsh McBirney, Gaithersburg, MD) and adjusted to 1,5 , or $10 \mathrm{~cm} \mathrm{~s}^{-1}$. Flow rates higher than $10 \mathrm{~cm} \mathrm{~s}^{-1}$ caused too severe turbulence to make effective linear measurements. Spores $\left(10 \mathrm{ml} \times 10^{7}\right.$ spores per $\left.\mathrm{ml}\right)$ were added to the tank at a point location, and their movement was de-
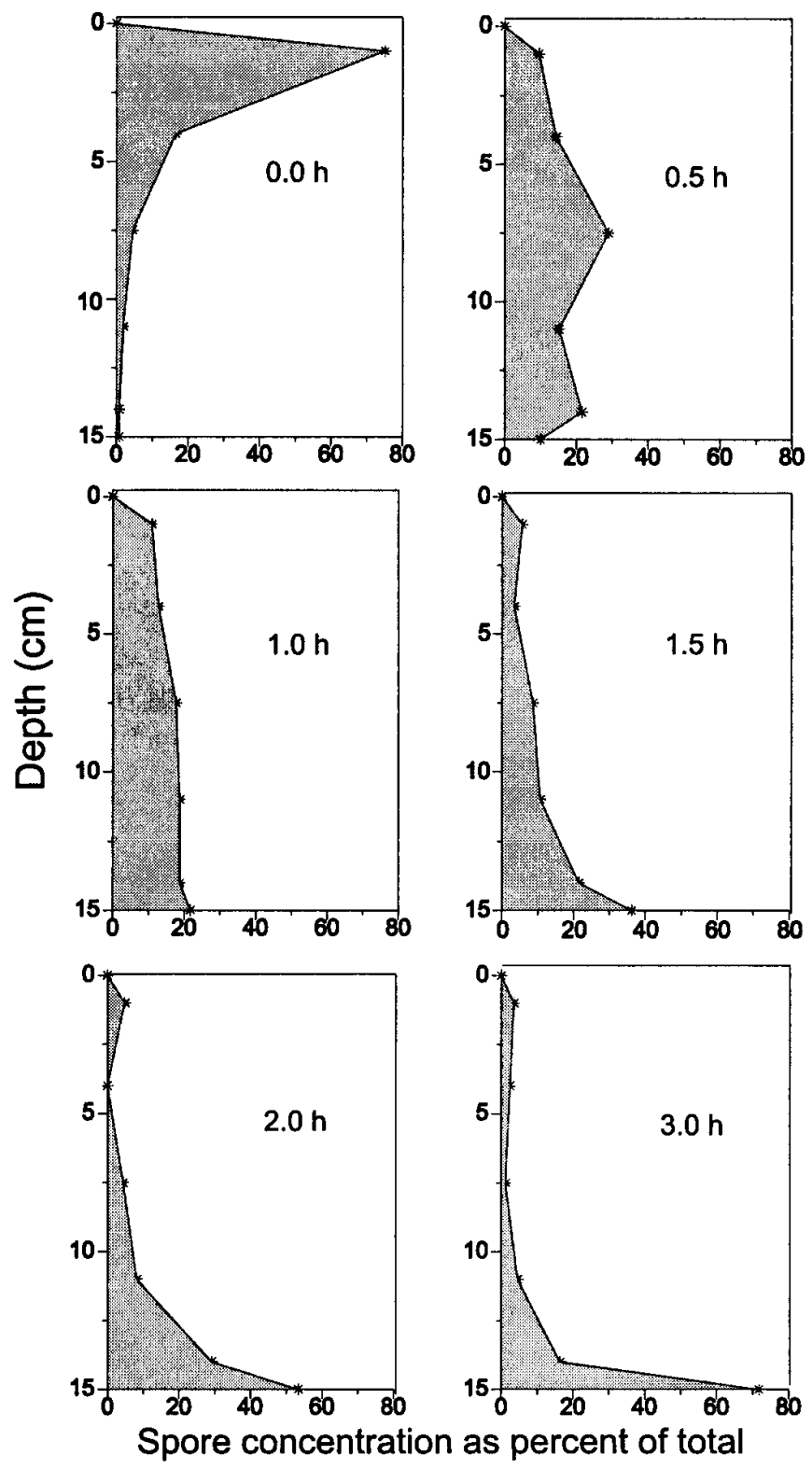

Fig. 4. Settlement of macroconidia of Fusarium culmorum in stationary containers of $5 \%$ Hoagland's+ over time. A spore suspension $\left(1 \mathrm{ml} \times 10^{6}\right.$ macroconidia per $\mathrm{ml}$ ) was added to the surface of the liquid. Samples of approximately $1 \mathrm{ml}$ were removed with a Pasteur pipette at depths of 1, 4, 7.5, 11, 14, and $15 \mathrm{~cm}$ at the following times: $0,0.5,1,1.5,2.0$, and $3.0 \mathrm{~h}$. Spore concentrations were quantified with a hemacytometer. Values are means from five experiments. 
termined by trapping. Spore samples were collected in 20-ml vials at four locations from the point of dispersal $(10,50,90$, and $130 \mathrm{~cm})$ and at depths of 10,20,30, and $40 \mathrm{~cm}$. The vials were sealed with aluminum foil using rubber bands and attached vertically to a PVC frame or to retort stands. The rate of flow was used to estimate the optimum sampling time, after addition of the spores, for each location. The spores were collected at each location by simultaneous penetration of the aluminum foil covering the sampling vials, at all four depths, using nails attached to a wooden frame. The vials were emptied into $60 \times 15$-mm standard petri plates, and the spores were counted as described above. Sampling was carried out four times at each of the three flow rates.

Determination of electrostatic charge on spores. The type of electrostatic charge on spores was determined by electrophoresis. Gels were prepared with one standard well and a 3-cm slot using $1 \%$ agarose (SeaKem; FMC Bioproducts, Rockland, ME) in Trisborate buffer, $\mathrm{pH} 8.3$ (18). Loading dye $(0.25 \%$ bromophenol blue) was added to the standard well and spores in Hoagland's+ $\left(200 \mu \mathrm{l}\right.$ at $2.5 \times 10^{6}$ spores per $\mathrm{ml}$ ) were added to the combined well. A charge of $25 \mathrm{~V}$ was applied, and the movement of the loading dye was monitored. After $1.5 \mathrm{~h}$, the gel was removed and examined microscopically for the location of the spores. The experiment was repeated twice with 1 -week-old macroconidia and 6 -week-old chlamydospores. The whole procedure was repeated using sodium phosphate buffer, $\mathrm{pH}$ 7.0, to replace Tris-borate buffer.

\section{RESULTS}

Spore settlement in still solutions. Macroconidia settled quickly in still aqueous solutions. The pattern of fall in 5\% Hoagland's+, which was typical for the different solutions, is shown in Figure 4. The macroconidia were concentrated at the top of the aqueous columns at time zero. After $30 \mathrm{~min}$, spores were found throughout the $15-\mathrm{cm}$ columns. After $2 \mathrm{~h}, 80 \%$ of spores were concentrated within $1 \mathrm{~cm}$ at the bottom. Spore settlement after $1 \mathrm{~h}$ and rate of fall were similar for DI water, tap water, Hoagland's+, spring water, and river water. After $1 \mathrm{~h}, 50 \%$ of the spores had fallen 9 $\mathrm{cm}$. There was no difference in the rate of fall between 1-weekold macroconidia and 6-week-old chlamydospores stored at $4{ }^{\circ} \mathrm{C}$. The rate of fall after $1 \mathrm{~h}$ was determined graphically by plotting the cumulative spore concentration at each depth (Fig. 5). A small proportion of the spores remained floating on the surface after $3 \mathrm{~h}$, and the fate of these spores was investigated in the following experiment. The concentration of floating spores in tap water, 5\% Hoagland's+, spring water, and river water fell rapidly after 1 day

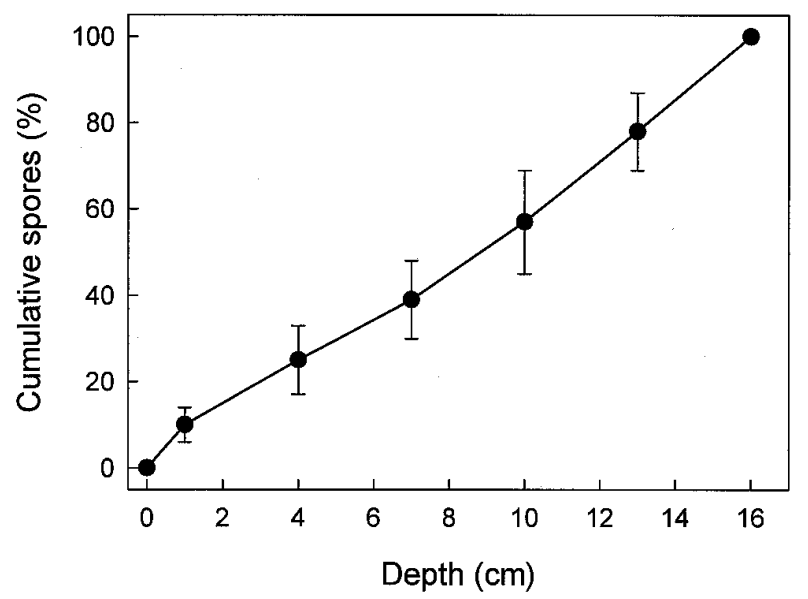

Fig. 5. Distribution of spores of Fusarium culmorum (cumulative percentage) at different depths sampled after $1 \mathrm{~h}$ in $5 \%$ Hoagland'st. Means \pm standard error (SE) are from nine separate experiments. and was reduced to undetectable levels after 4 days. There were no differences in the rate of fall among the solutions. Upon microscopic examination, 10 to $50 \%$ of the floating macroconidia were found to germinate in solution after 1 day. Spores that sank immediately did not germinate, but formed chlamydospores.
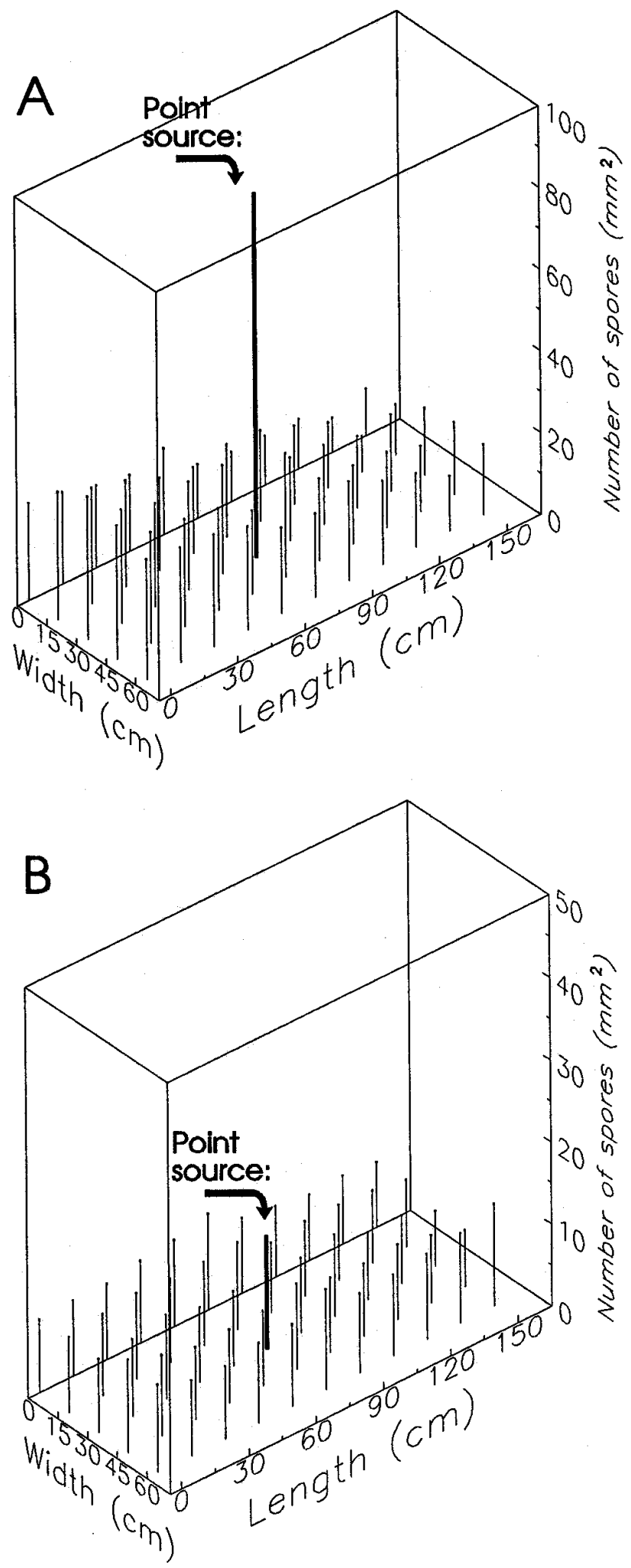

Fig. 6. Distribution of spores of Fusarium culmorum (spores per $\mathrm{mm}^{2}$ ) $24 \mathrm{~h}$ after dispersal from a point source in still water in a metal tank with rounded ends ( $290 \mathrm{~cm}$ long $\times 88 \mathrm{~cm}$ wide $\times 70 \mathrm{~cm}$ high) with a water depth of $\mathbf{A}, 10$ $\mathrm{cm}$; and $\mathbf{B}, 50 \mathrm{~cm}$. Each experiment was repeated twice with similar results. 
Spore dispersal from a point source. The spores settled with a relatively even distribution over the complete $60 \times 150-\mathrm{cm}$ area sampled with petri-plate traps placed in the $290 \times 88 \times 70$-cm container at depths of both 10 and $50 \mathrm{~cm}$ (Fig. 6A and B). At the 10-cm depth, there was a peak concentration of spores at the central point of spore introduction. This was considered to be due to physical contact between the spores and the petri-plate base at the time of application. Spore concentrations at depths of 10,25 , and $40 \mathrm{~cm}$, at a horizontal distance of $75 \mathrm{~cm}$ from the point source, were similar to those in the petri-plate traps over the entire sampling area. Thus, the lateral dispersal of spores occurred within minutes in the top $10 \mathrm{~cm}$ of the water.

Initial dispersal of spores from a point location was highly variable with sampling periods of 1 and $5 \mathrm{~min}$ (Fig. 7). Although variable, the initial movement of spores was also very rapid, as spores moved $15 \mathrm{~cm}$ in $1 \mathrm{~min}$. After $1 \mathrm{~h}$, the variability decreased as the spore concentration approached equilibrium. After $24 \mathrm{~h}$, the central sample plate had a high number of spores, but the spore numbers were almost uniform over the remainder of the container.

Spore dispersal in moving water. In moving water, the highest concentrations of spores were found at $10 \mathrm{~cm}$ from the dispersal point at the depths of 10 and $20 \mathrm{~cm}$ at all three rates of flow (Fig. $8 \mathrm{~A}, \mathrm{~B}$, and $\mathrm{C}$ ). The spores dispersed rapidly to a depth of $40 \mathrm{~cm}$ and along the full length of the sampling run. There was generally less downward movement of spores at the $10 \mathrm{~cm} \mathrm{~s}^{-1}$ flow rate than at the $1 \mathrm{~cm} \mathrm{~s}^{-1}$ flow rate, with faster horizontal movement of spores at higher flow rates. Flow rates above $10 \mathrm{~m} \mathrm{~s}^{-1}$ were attempted, but the turbulence was extreme with the production of small vortices, eddies, and chaotic flow, as shown by dye added to the water, and it was not possible to obtain meaningful patterns.

Determination of electrostatic charge on spores. After electrophoresis, the spores were located resting on the surface of the gel on the side closest to the negative pole. Migration of the spores over the surface of the gel towards the negative pole occurred for distances up to $3 \mathrm{~cm}$. This response occurred in all experiments with both Tris-borate buffer at $\mathrm{pH} 8.3$ and sodium phosphate buffer at $\mathrm{pH} 7.0$ and with macroconidia and chlamydospores. The consistent movement of the spores towards the negative pole was interpreted to indicate that the spores carried a positive charge.

\section{DISCUSSION}

Lateral dispersal of spores in water from a point source was surprisingly rapid. Spores moved at a rate in excess of $15 \mathrm{~cm} \mathrm{~min}^{-1}$, or over 100 times faster than the downward movement attributable to gravity. This initial movement was not regular and reproducible,

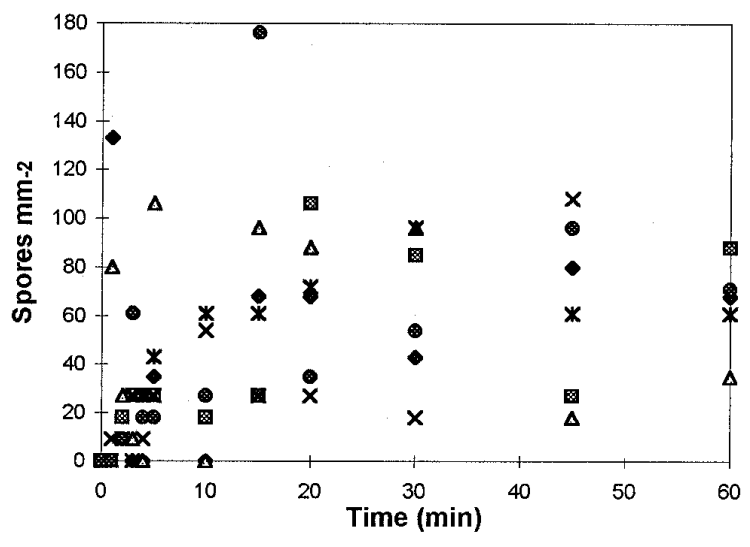

Fig. 7. Lateral dispersal of spores of Fusarium culmorum in still water sampled by means of spore traps $15 \mathrm{~cm}$ from the point source. The spore traps were removed at $0,1,2,3,4,5,10$, and $60 \mathrm{~min}$ or $0,5,10,15,20,30,45$, and $60 \mathrm{~min}$ after spore release. The data points from six replicate experiments are plotted. but variable and apparently chaotic. In the closed systems with still water, the spores moved to become regularly dispersed and evenly distributed throughout the water system. Convection currents are known to cause water movement in natural systems (25), but as the water temperature was constant over the course of the laboratory experiments, the dispersal of spores was not due to convection currents.

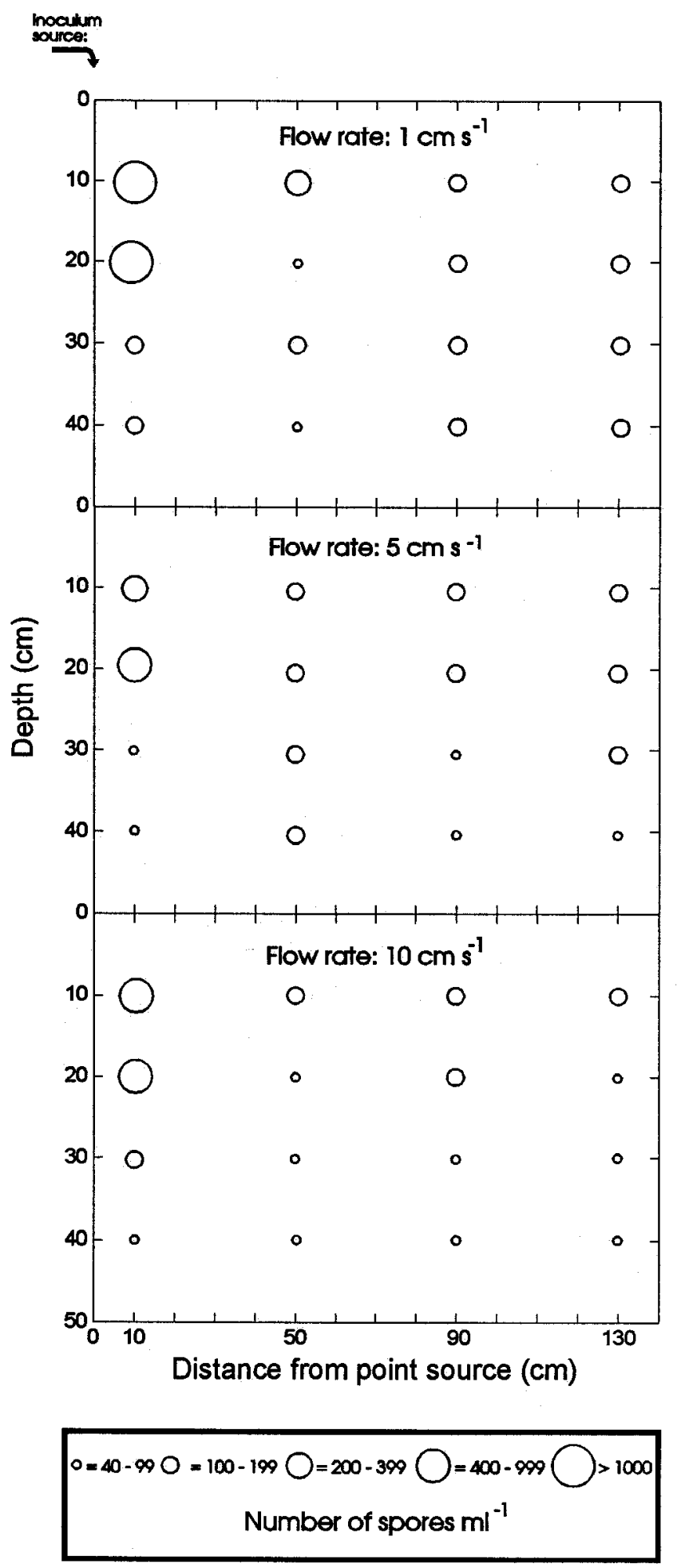

Fig. 8. Distribution of spores of Fusarium culmorum from a point source in moving water in a metal tank with rounded ends $(290 \mathrm{~cm}$ long $\times 88 \mathrm{~cm}$ wide $\times 70 \mathrm{~cm}$ high). Water movement was controlled by a trolling motor, and the flow rates were $\mathbf{A}, 1 \mathrm{~cm} \mathrm{~s}^{-1} ; \mathbf{B}, 5 \mathrm{~cm} \mathrm{~s}^{-1}$; and $\mathbf{C}, 10 \mathrm{~cm} \mathrm{~s}^{-1}$. Values, expressed as the number of spores per $\mathrm{ml}$, are the means from four experiments. 
F. culmorum spores carried a positive charge. Aerial spores of Agaricus campestris, Ganoderma applanatum, and Pholiota squarrosa also carried positive charges, while spores of Coprinus micaceus and Polyporus squamosus carried negative charges $(7,13)$. In contrast, most solid surfaces and bacteria are negatively charged $(16,24)$. In bacteria, the property of electrophoretic mobility varies among species (23).

The DLVO theory (due to Derjaguin, Landau, Verwey, and Overbeek) of colloid stability as applied to surfaces of living cells and inert surfaces may also be applicable to this system $(16,17,23)$. The theory proposes that the total long-term interaction between like-charged particles is composed of two additive terms, electrostatic repulsion and van der Waals attraction. The van der Waals forces occur at small distances between particles, where attraction is strong, and at large distances between particles, where attraction is weak. These are separated by a repulsion barrier caused by electrostatic charges at intermediate distances. We postulate that the positive electrostatic charges that occur on the F. culmorum spores are responsible for the rapid lateral movement and the final even distribution of spores in a closed body of water.

Spores of $F$. culmorum, both macroconidia and chlamydospores, are not buoyant but sink in a variety of aqueous solutions. This physical attribute of the spores is explained by Stokes' Law, which allows estimation of the rate of fall of a small sphere in a viscous fluid $(15,26)$. When a small sphere falls under the action of gravity through a viscous medium, it ultimately acquires a constant velocity. The spores of F. culmorum are canoe- or banana-shaped, and they are not of uniform size, so the rate of fall may vary for each individual spore. This gives the typical biological variation in the results, with the spores falling at various rates.

Spores were carried along by the dynamic flow of the water, while there were also dispersal and sinking of the spores. The dynamics of water movement and turbulence has been explained in recent years by the study of chaotic behavior and chaos theory (12). Chaotic systems, upon analysis, are nonlinear and dynamic; they are both deterministic and incorporate randomness $(1,14)$. Their sensitivity to initial conditions causes instability, and this leads to unpredictable results. The movement of spores in a river or a large body of water such as a lake could be modeled on the basis of chaos theory, incorporating a degree of uncertainty into the model.

The major implication for understanding of the epidemiology of underwater disease is the rapid dilution in inoculum concentration that occurs near the water surface in aquatic systems. This is caused by both the initial lateral dispersal of spores and the spore fall due to gravity. As spores are dispersed over a large area, there is a consequent reduction in spore concentration. As spores fall down the water column, the period of time in which the spore is floating freely, when it can make contact with the plant, is limited. In an independent study of lakes in Florida, it was found that plantpathogenic fungi, isolated frequently from aquatic plants and soil, were not routinely isolated from water samples (20). This might suggest that the presence of plants elicits a biological response from the spores (19), leading to their attraction towards the plants. However, this aspect was not investigated in our study.

To develop an effective biocontrol strategy, researchers will need to consider the rapid reduction in inoculum levels due to dispersal and settlement at nontarget sites. If spores are released from a point source, there will be a rapid reduction in the concentration of spores near the water surface, and initial patterns of dispersal will tend to be chaotic and, consequently, difficult to predict. Spores applied by spraying would tend to become evenly dispersed. The rapid spore fall also limits the effectiveness of the inoculum because of a reduction in the time possible for the spore to contact and become attached to the plant surface. Inoculum at the base of the water column is lost to the hydrillaF. culmorum pathosystem, but the spores remain viable, and are, therefore, potentially useful if they are able to attack hydrilla roots and tubers.
This is the first detailed description of the dispersal of spores of a nonmotile fungal pathogen in water. The dispersal of spores of F. culmorum in aquatic systems has been found to be surprisingly dynamic and complex. The main physical factors working independently to cause spore movement in still water are lateral dispersal and sinking due to gravity. In moving water, the dynamics of water movement is superimposed over the other two factors. Thus, the system includes the components of lateral dispersal of spores, spore fall due to gravity, and a chaotic system. This provides a conceptual framework for a dispersal model, not only of spores of Fusarium spp., but perhaps also for other underwater pathogens.

\section{ACKNOWLEDGMENTS}

This research was supported by USDA-CSREES-NRI competitive grant 95-37312-1656 and a Florida Department of Transportation, Environmental Management Office grant WI 0510742. Publication R-06126 Florida Agricultural Experiment Station journal series. We thank J. T. DeVelario and R. Robideaux for technical assistance, T. Davoli for help with modeling and computer graphics, and F. Burnet for statistical advice. We also thank D. J. Mitchell and H. C. Kistler for critically reviewing the paper.

\section{LITERATURE CITED}

1. Cambel, A. B. 1993. Applied Chaos Theory: A Paradigm for Complexity. Academic Press, Boston.

2. Charudattan, R. 1990. Biological control of aquatic weeds by means of fungi. Pages 186-201 in: Aquatic Weeds: The Ecology and Management of Nuisance Aquatic Vegetation. A. H. Pieterse and K. J. Murphy, eds. Oxford University Press, New York.

3. Charudattan, R., Freeman, T. E., Cullen, R. E., and Hofmeister, F. M. 1980. Evaluation of Fusarium roseum "Culmorum" as a biological control agent for Hydrilla verticillata: Safety. Pages 307-323 in: Proc. Int. Symp. Biol. Control Weeds, 5th. E. S. Delfosse, ed. CSIRO Publications, Canberra, Australia.

4. Charudattan, R., and McKinney, D. E. 1977. A Fusarium disease of the submerged aquatic weed Hydrilla verticillata. Proc. Am. Phytopathol. Soc. 4:222.

5. Charudattan, R., and McKinney, R. E. 1978. A Dutch isolate of Fusarium roseum "Culmorum" may control Hydrilla verticillata in Florida. Proc. Eur. Weed Res. Soc. Symp. Aquat. Weeds 5:219-224.

6. Goodwin, S. B., Cohen, B. A., Deahl, K. L., and Fry, W. E. 1994. Migration from northern Mexico as the probable cause of recent genetic changes in populations of Phytophthora infestans in the United States and Canada. Phytopathology 84:553-558.

7. Gregory, P. H. 1957. Electrostatic charges on spores of fungi in air. Nature 180:330.

8. Grove, G. G., Madden, L. V., and Ellis, M. A. 1985. Splash dispersal of Phytophthora cactorum from infected strawberry fruit. Phytopathology 75:611-615.

9. Hamilton, L. M., and Stakman, E. C. 1967. Time of stem rust appearance on wheat in the western Mississippi Basin in relation to the development of epidemics from 1921 to 1962. Phytopathology 57:609-614.

10. Hyde, K. D., Greenwood, R., and Jones, E. B. G. 1993. Spore attachment in marine fungi. Mycol. Res. 97:7-14.

11. Ingold, C. T. 1979. Advances in the study of so-called aquatic hyphomycetes. Am. J. Bot. 66:218-226.

12. Jensen, R. V. 1987. Classical chaos. Am. Sci. 75:168-181.

13. Leach, C. M. 1976. An electrostatic theory to explain violent spore liberation by Drechslera turcica and other fungi. Mycologia 68:63-86.

14. May, R. M. 1976. Simple mathematical models with very complicated dynamics. Nature 261:459-467.

15. McCoy, R. E. 1973. Ballistics of Mycosphaerella ligulicola ascospore discharge. Phytopathology 63:793-794.

16. Rutter, P. R., Dazzo, F. B., Freter, R., Gingell, D., Jones, G. W., Kjellborg, S., Marshall, K. C., Mrozek, H., Rades-Rohkohl, E., Robb, I. D., Silverman, M., and Tylewska, S. 1984. Mechanisms of adhesion. Pages 5-19 in: Microbial Adhesion and Aggregation. K. C. Marshall, ed. Springer-Verlag, Berlin.

17. Rutter, P. R., and Vincent, B. 1984. Physicochemical interactions of the substratum, microorganisms, and the fluid phase. Pages 21-38 in: Microbial Adhesion and Aggregation. K. C. Marshall, ed. Springer-Verlag, Berlin.

18. Sambrook, J., Fritsch, E. F., and Maniatis, T. 1989. Molecular Cloning: A Laboratory Manual. Cold Spring Harbor Laboratory Press, Cold Spring Harbor, NY. 
19. Schuerger, A. C., and Mitchell, D. J. 1993. Influence of mucilage secreted by macroconidia of Fusarium solani f. sp. phaseoli on spore attachment to roots of Vigna radiata in hydroponic nutrient solution. Phytopathology 83:1162-1170.

20. Shabana, Y. M., and Charudattan, R. 1996. Microorganisms associated with hydrilla in ponds and lakes in north Florida. J. Aquat. Plant Manage. 34:60-68.

21. Smither-Kopperl, M. L., Charudattan, R., and Berger, R. D. 1996. Epidemiology of an underwater disease: 1 . Settling and viability of macroconidia of Fusarium culmorum in aqueous solutions. (Abstr.) Phytopathology 86:S13.

22. Smither-Kopperl, M. L., Charudattan, R., and Berger, R. D. 1997. Epidemiology of an underwater disease: II. Settlement, viability, and germi- nation of spores of Fusarium culmorum, a potential biocontrol agent of hydrilla (Hydrilla verticillata [L.f.] Royle), in aqueous solutions. WSSA Abstr. 37:58.

23. van Loosdrecht, M. C. M., Lyklema, J., Noorde, W., Schraa, G., and Zehnder, A. J. B. 1987. The role of bacterial cell wall hydrophobicity in adhesion. Appl. Environ. Microbiol. 53:1893-1897.

24. van Loosdrecht, M. C. M., Lyklema, J., Noorde, W., Schraa, G., and Zehnder, A. J. B. 1987. Electrophoretic mobility and hydrophobicity as a measure to predict the initial steps of bacterial adhesion. Appl. Environ. Microbiol. 53:1898-1901.

25. Velarde, M. G., and Normand, C. 1980. Convection. Sci. Am. 243:92-108.

26. Weast, R. C., and Astle, M. J. 1994. Handbook of Chemistry and Physics, 75th ed. CRC Press, Boca Raton, FL. 